\title{
Molecular Epidemiology of Primary Brain Tumors
}

\author{
Jun $\mathrm{Gu}, *{ }^{*}$ Yanhong Liu, ${ }^{\dagger}$ Athanassios P. Kyritsis, ${ }^{\ddagger}$ and Melissa L. Bondy ${ }^{\dagger}$ \\ *School of Health Professions and ${ }^{\dagger}$ Department of Epidemiology, University of Texas, M.D. Anderson Cancer Center, Houston, \\ TX, 77030; and ${ }^{\ddagger}$ Neurosurgical Research Institute, University of Ioannina/Department of Neurology, University Hospital of \\ Ioannina, Ioannina, 45110, Greece
}

\begin{abstract}
Summary: Although primary brain tumors (PBTs) are generally considered to be a multifactorial disorder, understanding the genetic basis and etiology of the disease is essential for PBT risk assessment. Understanding of the genetic susceptibility for PBT has come from studies of rare genetic syndromes, linkage analysis, family aggregation, early-onset pediatric cases, and mutagen sensitivity. There are currently no effective markers to assess biological dose of exposures and genetic heterogeneity. The priorities recently recommended by the Brain Tumor Epidemiology Consortium emphasized the need for expanding research in genetics and molecular epidemiology. In this article, we review the literature to identify molecular epidemiologic case-control studies of PBTs that
\end{abstract}

were hypothesis-driven and focused on four hypothesized candidate pathways: DNA repair, cell cycle, metabolism, and inflammation. We summarize the results in terms of genetic associations of single nucleotide polymorphisms of these pathways. We also discuss future research directions based on available evidence and technologies, and conclude that high resolution whole genome approach with significantly large sample size could rapidly advance our understanding of the genetic etiology of PBTs. Literature searches were done on PubMed in March 2009 with the terms glioma, glioblastoma, brain tumor, association, and polymorphism, and we only reviewed English language publications. Key Words: Molecular epidemiology, brain tumors, genome-wide association, polymorphisms.

\section{INTRODUCTION}

The United States is among those countries where higher incidence rates of primary brain tumors (PBTs) are found. ${ }^{1,2}$ It is estimated that there are 22,000 new cases of PBTs and 13,000 deaths annually in the U.S. The Central Brain Tumor Registry of the United States

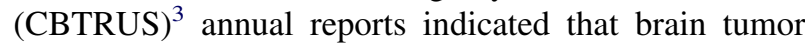
incidence was increasing over a 10 -year period from 1985 to 1994. CBTRUS data also showed that glioma accounts for $77 \%$ of PBTs, and patients with glioma have very poor survival. Although high-dose ionizing radiation and rare genetic syndromes are the only well established risk factors, ${ }^{4,5}$ they seem to account for only a small portion of all PBT cases. This observation supports hypotheses that PBTs genetically are a multifactorial disease rather than a condition that follows a mode of Mendelian inheritance or results from a single exposure. Moreover, variations at multiple loci might determine the

Address correspondence and reprint requests to: Melissa L. Bondy, Ph.D., Professor, Department of Epidemiology, M.D. Anderson Cancer Center, 1155 Pressler St, Unit 1340, Houston, TX 77030. E-mail: mbondy@mdanderson.org. expression of each gene. Hundreds of susceptible loci that are involved in single disorders are not always located in genes associated with disease risk. The variations at multiple loci contribute to the expression of each gene involved. ${ }^{6}$

Recently, genome-wide association studies (GWAS) with very large sample sizes and carefully matched controls have provided a powerful tool to identify genes involved in common human genetic diseases. ${ }^{7-11}$ This emergent technology can detect effects at the single nucleotide level. The identification of susceptibility alleles provides a greater understanding of carcinogenesis, potentially offering targets for therapeutic interventions. Unlike lifestyle exposure, single nucleotide polymorphisms (SNPs) do not change during the process of carcinogenesis. Therefore, SNPs could be suitable biomarkers in risk assessment. SNPs identified through this approach are associated with modest risk of PBTs, but this is just the beginning of the investigation of the complicated genetic basis of phenotypic variation. The most pressing challenge is how to link GWAS results with observed clinical and phenotypic changes. Possibly with genetic technology we might also be able to determine the racial differences of PBT incidence-in partic- 
ular why African Americans have such low incidence of developing PBTs.

This article reviews the literature for findings concerning the exploration of the genetic etiology of PBTs (mainly glioma) and identification of the knowledge gap in PBT research. Future direction is discussed based on available evidence and technologies.

\section{GENETIC CHANGES ASSOCIATED WITH SUSCEPTIBILITY}

PBT is considered to be a multifactorial disease. Accumulative DNA damage responsible for tumor transformation is the result of interactions between environmental exposure and genetic susceptibility. Although it is still hard to quantitatively determine the magnitude of environmental exposure and genetic susceptibility, the accuracy of risk assessment is improved with the improvement of genotyping resolution and whole genome approaches. Genetic susceptibility of PBT comes from rare genetic syndromes, family history of multiple cancers, chromosome changes, and linkage analysis. The improved resolution of genetic testing helps us understand the role of genetic polymorphisms, specifically in pathways such as DNA repair, cell cycle, inflammation, angiogenesis, and metabolic genes in the process of brain tumor carcinogenesis. It has been suggested that the initial genetic event of PBT involves genetic polymorphism and mutation of DNA repair and apoptosis genes. Subsequent somatic mutations in cell cycle control and angiogenesis genes are essential for malignant transformation. Rare genetic disorders such as Li-Fraumeni syndrome, neurofibromatosis (NF) type 1 and type 2, tuberous sclerosis, Turcot's syndrome, and familial polyposis support inherited predisposition to PBTs. ${ }^{12-14}$ Comparative genomic hybridization (CGH) analysis of familial PBTs aimed to reveal disease-specific chromosomal changes and thus identified a spectrum of chromosomal losses and gains. ${ }^{15,16}$ The epidemiologic evidence is suggestive for association between PBT and family history of cancer. Many studies have reported familial aggregation of glioma. ${ }^{17-23}$ As familial aggregation of cancers could be a sign of genetic etiology, we suspect that there are alleles responsible for familial aggregation observed in PBT patients and that these alleles could be revealed by GWAS analysis. The same assumption might be true for early-onset pediatric PBT cases.

\section{Cytogenetic markers used for molecular epidemiology in PBTs}

Molecular cytogenetic analysis of familial PBTs primarily focused on studying genes possibly associated with the disease, especially TP53, PTEN, CDKN2A, and $C D K 4$ genes. However, germline mutations did not increase significantly for familial PBTs. ${ }^{24,25}$ In 2002,
Paunu et $\mathrm{al}^{26}$ performed the first linkage study for familial glioma, investigating 15 familial glioma pedigrees by using a two-stage disease gene mapping strategy for low-penetrance alleles. Their result indicated that $15 q 23$ $q 26.3$ harbors a novel susceptibility allele for familial glioma, and since their finding, improved higher resolution molecular genetic technology has marked the progress of mapping genetic changes in PBTs. Bredel et $\mathrm{al}^{27}$ conducted a high-resolution mapping by using cDNA microarray CGH technology to profile genetic changes with 42,000 cDNA clones in a cohort of 54 glioma patients and identified five novel minimally deleted loci thought to be important in gliomagenesis. The study successfully predicted astrocytoma and oligodendroglioma with $92 \%$ and $88 \%$ accuracy, respectively, based on 170 gene copy number patterns. Their findings implied that some early genetic changes necessary for gliomagenesis may be shared within the same histological groups and might be used for tumor classification. The first genome-wide analysis of pediatric PBTs for DNA copy number changes and loss of heterozygosity (LOH) by using SNP array was reported by Wong et al, ${ }^{28}$ who used a chip containing 11,562 SNPs, and analyzed 14 high-grade and 14 low-grade pediatric glioma. Wong et al found no detectable LOH for low-grade glioma, various degrees of LOH for high-grade cases, and amplification on EGFR and PDGFRA loci. They eventually validated their results by sequencing and quantitative PCR.

\section{PBTs molecular epidemiologic studies with focus on DNA repair}

DNA repair genes are a key factor in maintaining genomic stability. We have listed about 20 epidemiological studies reporting positive associations between DNA repair polymorphisms and cancer risk (Table $1^{29-45}$ ). Only a small proportion of studies were large (five studies were more than 500 pair cases and controls) and population based; however, some consistencies in results are apparent. Primarily, of the 17 genes associated with glioma risk, eight were from the double-strand breaks repair (DSBR) pathway, suggesting a strong link between DSBR and glioma. Although the etiology of gliomas remains unclear, ionizing radiation (IR) has been identified as the well established risk factor. IR induces various types of DNA damages, particularly DSBs that are the major threats to the genomic integrity of cells. Considering that DSBR is the most important DNA repair pathway to deal with such damage, it is very likely that the SNPs in the DSBR could play an important role in carcinogenesis. Second, three genes, ERCC1, ERCC2, and especially $M G M T$, a gene involved in repairing alkylated quinine in DNA, were consistently associated with glioma risk across three different studies from three different populations (whites, Japanese, and Caucasians), 
Table 1. PBT Molecular Epidemiologic Studies with Focus on DNA Repair

\begin{tabular}{|c|c|c|c|c|c|}
\hline $\begin{array}{l}\text { Disease } \\
\text { Type }\end{array}$ & Pathway Gene & $\begin{array}{c}\text { Association } \\
\mathrm{Y} / \mathrm{N}\end{array}$ & Population & Sample Size & $\begin{array}{c}\text { References } \\
\text { (Year) }\end{array}$ \\
\hline \multirow[t]{27}{*}{ Glioma } & Double strand break repair & & & & \\
\hline & XRCC3 & $\mathrm{Y}$ & Chinese & 771 cases, 752 controls & 29 (2009) \\
\hline & & $\mathrm{Y}$ & Caucasian & 844 cases, 1560 controls & $30(2008)$ \\
\hline & XRCC4, LIG4 & Y & Chinese & 771 cases, 752 controls & $31(2008)$ \\
\hline & XRCC5, XRCC6 & Y & Chinese & 771 cases, 752 controls & $32(2007)$ \\
\hline & $X R C C 7$ & Y & Caucasian & 309 cases, 342 controls & $33(2004)$ \\
\hline & $B R C A 1, E M E 1$ & $\mathrm{Y}$ & Caucasian & 112 cases, 112 controls & 34 (2008) \\
\hline & Base excision repair & & & & \\
\hline & APEXI, XRCCI, PARPI (ADPRT) & Y & Caucasian & 373 cases, 365 controls & 35 (2009) \\
\hline & $X R C C 1$ & Y & Caucasian & 844 cases, 1560 controls & $30(2008)$ \\
\hline & Nucleotide excision repair & & & & \\
\hline & $E R C C 1$ & Y & White & 122 cases, 159 controls & $36(2000)$ \\
\hline & & $\mathrm{Y}$ & White & 450 cases, 500 controls & $37(2005)$ \\
\hline & & $\mathrm{Y}$ & Caucasian & 373 cases, 365 controls & 35 (2009) \\
\hline & $E R C C 2(X P D)$ & Y & White & 187 cases, 169 controls & $38(2001)$ \\
\hline & & Y & White & 141 cases, 108 controls & $39(2005)$ \\
\hline & & Y & White & 450 cases, 500 controls & $37(2005)$ \\
\hline & LIG1 & Y & Caucasian & 373 cases, 365 controls & 35 (2009) \\
\hline & Direct reversal of damage & & & & \\
\hline & $M G M T$ & $\mathrm{Y}$ & White & 453 cases, 526 controls & 40 (2007) \\
\hline & & Y & Japanese & 74 cases, 255 controls & $41(2003)$ \\
\hline & & Y & Caucasian & 373 cases, 365 controls & $35(2009)$ \\
\hline & Chromatin Structure & & & & \\
\hline & CHAF1A & Y & Caucasian & 1013 cases, 1016 controls & $42(2008)$ \\
\hline & Others & & & & \\
\hline & EXO1 & $\mathrm{Y}$ & Caucasian & 112 cases, 112 controls & 34 (2008) \\
\hline & $W R N$ & $\mathrm{~N}$ & Brazilian & 94 cases, 100 controls & $43(2008)$ \\
\hline \multirow[t]{2}{*}{ Meningioma } & ERCC2, Ki-ras & $\mathrm{Y}$ & Israel & 440 cases & 44 (2005) \\
\hline & $R A D 54 L$ & Y & Spain and Ecuador & 70 cases, 287 controls & 45 (2003) \\
\hline
\end{tabular}

which strongly suggests that they may be involved in carcinogenesis. A recent European study revealed that CHAF1A, a gene coded for Chromatin assembly factor, is associated with increased glioma risk. Additional epidemiological analyses of these and other DNA repair gene polymorphisms will provide essential information about the in vivo relationships between the DNA repair mechanisms and carcinogenesis and will complement in vitro analysis.

\section{PBTs molecular epidemiologic studies with focus on cell cycle}

Glial cell proliferation is considered important in gliomagenesis. Studies that looked at the correlations between cell cycle genes and glioma risk did not generate a clear pattern (Table $2^{43,46-70}$ ). The positive association between $E G F / E G F R$ and glioma risk was observed in majority of the case-control studies published. However, studies of PTEN and TP53 genes and glioma risk gave contradictory results. $C A S P 8$, a gene that plays a critical role in the execution phase of programmed cell death, $C D K N 2 A$ (cyclin-dependent kinase inhibitor 2A), an important tumor suppressor gene that is frequently deleted in many tumors, and $C X 3 C R 1$, a chemokine receptor 1 gene, have recently been reported to be risk-bind genes and will need further validation. HRAS and MDM2, genes involved in signal transduction pathway and inactivation of tumor protein $\mathrm{p} 53$, were reported to be not associated with glioma risk. $M M P 7, N F 1$, and $T P 53$ were linked to the risk of astrocytoma, but the results require further confirmation. CASP8 is also reported to be associated with the risk of meningioma. Results for astrocytoma and meningioma risk were not sufficient to draw any conclusions.

\section{PBTs molecular epidemiologic studies with focus on metabolism}

Our review indicated that currently available studies do not provide enough supportive information to establish genes involved in metabolism for PBT risk assessment (Table $3^{71-83}$ ). Contradictory results were observed for MTHFR, MTRR, NAT2, and PON1 for glioma. SOD2, $S O D 3$, and $C A T$ were positively linked to glioma risk in a recent study. The association was not indicated for CYP1A1, GSTT11, GSTM1, GSTM3, and NQO1. This is inconsistent with data from meta-analysis. A meta-analysis of eight studies with 1,630 gliomas, 245 meningiomas, and 7,151 controls found no association between glutathione S-transferases (GST) variants and adult brain tumors. ${ }^{84}$ Neural carcinogens, such as dietary N-nitroso 
Table 2. PBT Molecular Epidemiologic Studies with Focus on Cell Cycle

\begin{tabular}{|c|c|c|c|c|c|}
\hline Disease Type & Pathway Gene & Association $\mathrm{Y} / \mathrm{N}$ & Population & Study Info & $\begin{array}{l}\text { References } \\
\text { (Year) }\end{array}$ \\
\hline \multirow[t]{28}{*}{ Glioma } & \multirow[t]{5}{*}{ TP53 } & $\mathrm{Y}$ & & 135 cases & $46(2005)$ \\
\hline & & $\mathrm{Y}$ & USA & 22 cases only (mutations) & 47 (1995) \\
\hline & & $\mathrm{Y}$ & Chinese & 44 cases only (mutations) & 48 (1999) \\
\hline & & $\mathrm{N}$ & Brazilian & 94 cases, 100 controls & $43(2008)$ \\
\hline & & $\mathrm{N}$ & Japanese & 113 cases & $49(2004)$ \\
\hline & \multirow[t]{4}{*}{$E G F$} & $\mathrm{Y}$ & USA & 42 cases only (mutations) & $50(2004)$ \\
\hline & & $\mathrm{Y}$ & Caucasian & 188 cases, 176 controls & $51(2006)$ \\
\hline & & $\mathrm{Y}$ & & 197 case, 570 controls & $52(2007)$ \\
\hline & & $\mathrm{N}$ & Caucasian & 209 cases, 214 controls & $53(2007)$ \\
\hline & \multirow{4}{*}{$E G F R$} & Y & & 70 cases only (mutations) & 54 (1997) \\
\hline & & $\mathrm{N}$ & Brazilian & 193 cases, 200 controls & $55(2008)$ \\
\hline & & Y & USA & 174 cases; cohort & $56(2001)$ \\
\hline & & $\mathrm{N}$ & Japanese & 113 cases & 49 (2004) \\
\hline & \multirow[t]{3}{*}{ PTEN } & $\mathrm{Y}$ & Japanese & 26 cases only (mutations) & $57(2004)$ \\
\hline & & $\mathrm{N}$ & Turkish & 62 cases only & $58(2007)$ \\
\hline & & Y & USA & 174 cases; cohort & $56(2001)$ \\
\hline & \multirow[t]{2}{*}{$M D M 2$} & $\mathrm{~N}$ & & 98 cases, 102 controls & $59(2008)$ \\
\hline & & $\mathrm{N}$ & Japanese & 254 cases, 50 controls & $60(2007)$ \\
\hline & \multirow[t]{2}{*}{$C D K N 2 A$} & Y & & 45 cases only & $61(2003)$ \\
\hline & & $\mathrm{N}$ & & 36 families, with 44 patients & $62(1997)$ \\
\hline & $N F 1$ & $\mathrm{Y}$ & & 12 cases only & $63(2003)$ \\
\hline & $P I K 3 C A$ & $\mathrm{Y}$ & US & 73 cases only & $64(2006)$ \\
\hline & $M M P 1$ & $\mathrm{Y}$ & & 81 cases, 57 controls & $65(2005)$ \\
\hline & $M M P 7$ & $\mathrm{Y}$ & Chinese & 221 cases, 366 controls & $66(2006)$ \\
\hline & $H R A S$ & $\mathrm{~N}$ & White & 73 cases, 65 controls & $67(2000)$ \\
\hline & CASP8 & $\mathrm{Y}$ & Caucasian & 1005 cases, 1011 controls & $68(2008)$ \\
\hline & $C D K N 2 B, C D K 4$ & $\mathrm{~N}$ & & 36 families, with 44 patients & $62(1997)$ \\
\hline & $C X 3 C R 1$ & Y & France & 208 cases only & $69(2008)$ \\
\hline Meningioma & CASP8 & $\mathrm{Y}$ & $\begin{array}{l}\text { White, Black, and } \\
\text { Other }\end{array}$ & 623 cases, 799 controls & $70(2007)$ \\
\hline
\end{tabular}

compounds (NOCs) from consumption of cured meats, were studied for the risk of gliomas. A pooled analysis of nine population-based studies failed to establish NOCs as a causal agent for glioma. ${ }^{85}$

\section{PBTs molecular epidemiologic studies with focus on inflammation}

An inverse association between $I L-4 R A, I L-13$, and glioblastoma was observed and the relationship was not affected by allergic conditions (Table $4^{86-92}$ ). The studies also provide evidence to establish allergies as a risk factor for glioma and thus urge the identification of more candidate genes to be studied under this category. Furthermore, a meta-analysis of 3,450 gliomas and 1,070 meningiomas from eight observation studies found a strong inverse relationship between history of asthma, eczema, hay fever, or allergy and brain tumor. ${ }^{93}$ SNP analysis of $I L-4, I L-4 R A$, and $I L-13$ was demonstrated to be a better approach for overcoming the recall bias of self-reporting allergies and increased post diagnostic immunoglobulin E levels. However, it remains unclear whether allergies protect against tumors or whether immunosuppressive gliomas inhibit allergies. The consistency of these findings suggests a possible role in glio- magenesis for immunologic factors and inflammation, clearly warranting more investigation of immune function genes.

\section{DISCUSSION AND FUTURE DIRECTIONS}

In summary, among the polymorphisms in DNA repair, cell cycle, metabolism, and inflammation pathways, the DNA repair and inflammation pathways, in particular the DSBR sub-pathway, may play important roles in the initiation of glioma. However, despite the promise of all of the molecular epidemiology information accumulated over the years, there is currently little or no knowledge of the functional relevance of these polymorphisms that are being studied. Therefore, in addition to emphasizing large, well designed epidemiological studies, gene environment and gene-gene interactions, future studies should emphasize the functional relevance of polymorphisms and their correlation with repair phenotypes to help further illuminate the complex landscape of molecular epidemiology and PBT risk. (Studies in which the pathway gene was not specified are shown in Table $5 .^{39,94-101}$ ) 
Table 3. PBT Molecular Epidemiologic Studies with Focus on Metabolism

\begin{tabular}{|c|c|c|c|c|c|}
\hline Disease Type & Pathway Gene & $\begin{array}{c}\text { Association } \\
\text { Y/N }\end{array}$ & Population & Study Info & $\begin{array}{l}\text { References } \\
\text { (Year) }\end{array}$ \\
\hline \multirow[t]{3}{*}{$\begin{array}{l}\text { Acoustic neuroma, } \\
\text { Glioma, } \\
\text { Meningioma }\end{array}$} & $\begin{array}{l}\text { CYP1A1, CYP1B1, } \\
\text { GSTM3, NQO1, } \\
\text { EPHX1 }\end{array}$ & $\mathrm{N}$ & $\begin{array}{l}\text { White, Black and } \\
\text { Other }\end{array}$ & 782 cases, 799 controls & $71(2006)$ \\
\hline & $C Y P 2 E 1$ & $\mathrm{Y}$ & $\begin{array}{l}\text { White, Black and } \\
\text { Other }\end{array}$ & 673 cases, 799 controls & $72(2003)$ \\
\hline & $S O D 2, S O D 3, C A T$ & $\mathrm{Y}$ & Non-Hispanic White & 465 cases, 494 controls & $73(2008)$ \\
\hline \multirow[t]{14}{*}{ Glioma } & GSTM1 & $\mathrm{Y}$ & & 394 cases only & $74(2002)$ \\
\hline & & $\mathrm{N}$ & Caucasian & 725 cases, 1612 controls & $75(2007)$ \\
\hline & NAT2 & $\mathrm{Y}$ & $\begin{array}{l}\text { Caucasian, African- } \\
\text { American }\end{array}$ & 90 cases, 90 controls & $76(1998)$ \\
\hline & & $\mathrm{N}$ & & 159 cases, 163 controls & $77(2001)$ \\
\hline & PON1 & $\mathrm{Y}$ & Turkish & 84 cases, 50 controls & $78(2006)$ \\
\hline & & $\mathrm{N}$ & $\begin{array}{l}\text { White, African- } \\
\text { American, Asian } \\
\text { and Other }\end{array}$ & 66 cases, 236 controls & $79(2005)$ \\
\hline & MTHFR, MTR & $\mathrm{Y}$ & UK Caucasian & 1005 cases, 1101 controls & $80(2008)$ \\
\hline & & $\mathrm{N}$ & Caucasian & 328 cases, 400 controls & $81(2006)$ \\
\hline & $N Q O 1$ & $\mathrm{~N}$ & Caucasian & 725 cases, 1612 controls & 75 (2007) \\
\hline & & $\mathrm{N}$ & & 159 cases, 163 controls & $77(2001)$ \\
\hline & GSTP1 & $\mathrm{Y}$ & & 394 cases only & $74(2002)$ \\
\hline & GSTs & $\mathrm{N}$ & $\begin{array}{l}\text { Caucasian, African- } \\
\text { American, and } \\
\text { Other }\end{array}$ & 367 cases, 428 controls & $82(2004)$ \\
\hline & $\begin{array}{l}\text { GSTM3, GSTT1, } \\
\text { CYPIA1 }\end{array}$ & $\mathrm{N}$ & Caucasian & 725 cases, 1612 controls & 75 (2007) \\
\hline & $M D R 1$ & $\mathrm{~N}$ & Caucasian & 458 cases, 528 controls & $83(2005)$ \\
\hline
\end{tabular}

We constructed a working hypothesis diagram for gliomagenesis because most of the studies reviewed were predominantly dealing with glioma (FIG. 1). Understanding the genetic etiology of PBT is essential to understand the familial aggregation, ethnic differences, age preferences, and high-risk exposure of the disease. High-penetrance genetic abnormalities that influence PBTs involve the $N F 1$ gene, $p 53$ gene, $M M R$ genes, $A P C$ gene, and only rarely the PTEN, p16 (INK4A)/p14 (ARF), and $C D K 4$. However, risk from high-penetrance germline mutations only accounts for a very small por- tion of overall risk when compared to those from lowpenetrance germline mutations. It is evidenced that many newly identified susceptibility SNPs via high-throughput whole genome approaches are significantly associated with only low risk of the disease, suggesting multiple gene groups involved in different steps of the genetic pathway. Although it is not established that the effects at the single nucleotide level might be causative for the disease, we presented studies of the genetic polymorphisms of both high and low penetrance genes, especially multiple genes that regulate various DNA repair path-

Table 4. PBT Molecular Epidemiologic Studies with Focus on Inflammation

\begin{tabular}{|c|c|c|c|c|c|}
\hline Diseases Type & Pathway Gene & $\begin{array}{c}\text { Association } \\
\text { Y/N }\end{array}$ & Population & Study Info & References (Year) \\
\hline \multirow[t]{13}{*}{ Glioma } & $I L A R$ & $\mathrm{Y}$ & Caucasian & 694 cases only & $86(2008)$ \\
\hline & & $\mathrm{Y}$ & Caucasian & 456 cases, 541 controls & 87 (2007) \\
\hline & & Y & & 111 cases, 422 controls & $88(2005)$ \\
\hline & & $\mathrm{Y}$ & Caucasian & 217 cases, 1171 controls & 89 (2007) \\
\hline & ILA & $\mathrm{Y}$ & & 756 cases, 1190 controls & $90(2007)$ \\
\hline & & $\mathrm{Y}$ & Caucasian & 456 cases, 541 controls & 87 (2007) \\
\hline & IL13 & $\mathrm{Y}$ & & 111 cases, 422 controls & $88(2005)$ \\
\hline & & $\mathrm{Y}$ & Caucasian & 373 cases, 365 controls & 91 In press (2009) \\
\hline & & $\mathrm{Y}$ & Caucasian & 456 cases, 541 controls & $87(2007)$ \\
\hline & IL10, COX2 & Y & Caucasian & 373 cases, 365 controls & 91 In press (2009) \\
\hline & IL6 & $\mathrm{Y}$ & & 756 cases, 1190 controls & $90(2007)$ \\
\hline & PTGS2, ADAM33 & $\mathrm{Y}$ & & 111 cases, 422 controls & $88(2005)$ \\
\hline & TNFb4 & $\mathrm{Y}$ & Italy & 58 cases, 95 controls & $92(1999)$ \\
\hline
\end{tabular}


Table 5. PBT Molecular Epidemiologic Studies with Pathway Gene not Specified

\begin{tabular}{|c|c|c|c|c|c|}
\hline Diseases Type & Pathway Gene & $\begin{array}{c}\text { Association } \\
\mathrm{Y} / \mathrm{N}\end{array}$ & Population & Study Info & $\begin{array}{l}\text { References } \\
\text { (Year) }\end{array}$ \\
\hline \multirow[t]{7}{*}{ Glioma } & IDHI & Y & & 22 cases only (mutations) & $94(2008)$ \\
\hline & & Y & & 445 cases, 494 controls & 95 (2009) \\
\hline & IDH2 & $\mathrm{Y}$ & & 445 cases, 494 controls & 95 (2009) \\
\hline & hTERT & $\mathrm{Y}$ & France & 352 cases, 305 controls & $96(2007)$ \\
\hline & $C T N N B 1, A P C$ & $\mathrm{~N}$ & UK & 77 cases only & 97 (2006) \\
\hline & GLTSCR1 & $\mathrm{Y}$ & Caucasians & 141 cases, 108 controls & $39(2005)$ \\
\hline & $\begin{array}{c}I G F 1, I G F 1 R, I G F 2, \\
I G F 2 R, I G F B P 3\end{array}$ & $\mathrm{~N}$ & Non-Hispanic White & 487 cases, 495 controls & $98(2008)$ \\
\hline \multirow[t]{2}{*}{ Meningioma } & $A L A D$ & $\mathrm{Y}$ & $\begin{array}{l}\text { Caucasian, African- } \\
\text { American, and } \\
\text { Other }\end{array}$ & 686 cases, 799 controls & 99 (2006) \\
\hline & & $\mathrm{Y}$ & $\begin{array}{l}\text { Caucasian, African- } \\
\text { American, and } \\
\text { Other }\end{array}$ & 782 cases, 799 controls & $100(2005)$ \\
\hline $\begin{array}{l}\text { Glioma and } \\
\text { Memingioma }\end{array}$ & SULT1A1 & $\mathrm{Y}$ & Turkish & 60 cases, 156 controls & $101(2008)$ \\
\hline
\end{tabular}

ways, which is important to understand the predisposition to PBTs. Initial predisposing events involve genes regulating DNA repair and apoptosis that lead to further somatic events and the formation of PBTs. It occurs more frequently in families with a history of multiple cancers, early-onset pediatric PBTs, and occasionally in random PBTs. On the other hand, the majority of PBT risk is from unknown somatic mutations and the interaction between all mutations and environmental exposure. Few studies have detailed measurements of expo- sures or gene-exposure interactions. Better exposure measurements, such as internal dose and biological effective dose, need to be developed so that both genetic susceptibility and exposure may be accurately estimated for overall PBT risk assessment. The heterogeneity of exposures, susceptibility, and tumor types requires current and future research to identify additional germline polymorphisms. A long-term goal would be to incorporate these associations with epidemiologic data to develop a risk-assessment model, an effort which could

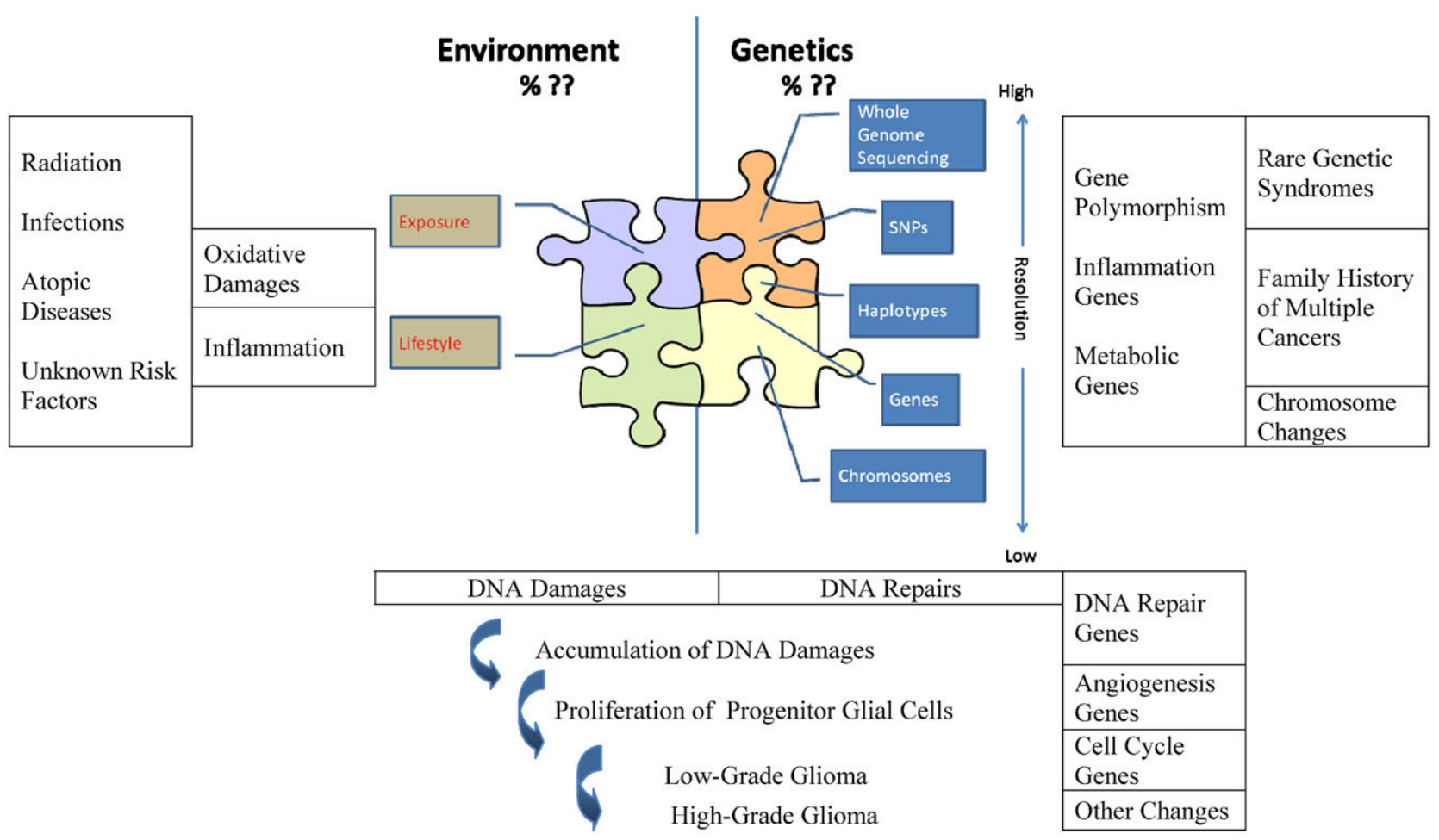

FIG. 1. Working hypothesis of gliomagenesis. 
also improve classification of PBTs into more homogenous groups by using molecular markers.

In order to study familial aggregation by using the whole genome SNPs approach, an international consortium, GLIOGENE, ${ }^{102}$ was assembled in 2007 with the aim of identifying families with two or more glioma cases for linkage analysis. GLIOGENE is considered the first international collaborative effort to investigate familial glioma regarding shared genetic defects. Recent molecular epidemiologic studies of PBTs included larger samples sizes and better designed SNP analysis, but most of these studies were based on the molecular pathway proposed and covered limited genetic loci. As the technology improves, a whole genome non-hypothesis driven approach with higher resolution will be able to identify disease-specific susceptibility loci in order to better understand the genetic etiology associated with PBT risk. To further expedite our understanding of the molecular basis of cancer, a comprehensive and coordinated effort from the Cancer Genome Atlas (TCGA), funded by the National Institutes of Health, has been put forward to apply several profiling modalities in a high throughput fashion to three cancer types. Glioblastoma, ${ }^{103}$ squamous cell lung cancer, and ovarian carcinoma were selected due to their poor prognosis and the relatively large amounts of high-quality tissue samples in biorepositories. The modalities used to characterize the numerous samples include DNA sequencing of a select number of genes, gene expression by microarray, CGH arrays, methylation arrays, and microRNA microarrays. The output from TCGA and other high-throughput projects is still being evaluated, and it is likely that further exciting findings will be made in these datasets.

\section{Disclosure}

Funding was provided by NIH grants 5R01 CA119215 and 5R01 CA070917.

\section{REFERENCES}

1. Inskip P, Linet $M$, Heineman E. Etiology of brain tumors in adults. Epidemiol Rev 1995;17:382-414.

2. Wrensch M, Minn Y, Chew T, Bondy M, Berger M. Epidemiology of primary brain tumors: current concepts and review of the literature. Neuro Oncol 2002;4:278-299.

3. Central Brain Tumor Registry of the United States. Available at: http://www.CBTRUS.org. Accessed April 16, 2009.

4. Melean G, Sestini R, Ammannati F, Papi L. Genetic insights into familial tumors of the nervous system. Am J Med Genet C Semin 2004;129:74-84.

5. Sadetzki S, Chetrit A, Freedman L, Stovall M, Modan B, Novikov I. Long-term follow-up for brain tumor development following childhood exposure to ionizing radiation for tinea capitis. Radiat Res 2005;163:424-432.

6. Kruglyak L. The road to genome-wide association studies. Nat Genet 2008;9:314-318.

7. Easton D, Pooley K, Dunning A, et al. Genome-wide association study identifies novel breast cancer susceptibility loci. Nature 2007;447:1087-1093.

8. Gudmundsson J, Sulem P, Manolescu A, et al. Genome-wide association study identifies a second prostate cancer susceptibility variant at 8q24. Nat Genet 2007;39:631-637.

9. Tomlinson I, Webb E, Carvajal-Carmona L, et al. A genome-wide association scan of tag SNPs identifies a susceptibility variant for colorectal cancer at 8q24.21. Nat Genet 2007;39:984-988.

10. Yeager M, Orr N, Hayes R, et al. Genome-wide association study of prostate cancer identifies a second risk locus at 8q24. Nat Genet 2007;39:645-649.

11. Zanke B, Greenwood C, Rangrej J, et al. Genome-wide association scan identifies a colorectal cancer susceptibility locus on chromosome 8q24. Nat Genet 2007;39:989-994.

12. Melean G, Sestini R, Ammannati F, et al. Genetic insights into familial tumors of the nervous system. Am J Med Genet C Semin 2004;129:74-84.

13. Lengauer C, Kinzler KW, Vogelstein B. Genetic instabilities in human cancers. Nature 1998;396:643-649.

14. Beckman R, Loeb L. Genetic instability in cancer: theory and experiment. Semin Cancer Biol 2005;15:423-435.

15. Patel A, van Meyel D, Mohapatra G, et al. Gliomas in families: chromosomal analysis by comparative genomic hybridization. Cancer Genet Cytogenet 1998;100:77-83.

16. Schwartzbaum J, Fisher J, Aldape K, et al. Epidemiology and molecular pathology of glioma. Nat Clin Pract Neurol 2006;2: 494-503.

17. Van der Weil HJ. Inheritance of glioma. New York: Elsevier; 1960.

18. Metzel E. Betrachtungen zur Genetik der famili_ren Gliome. Acta Genet Med Gemellol (Roma) 1964;13:124-131.

19. Choi N, Schuman L, Gullen W. Epidemiology of primary central nervous system neoplasms. II. Case control study. Am J Epidemiol 1970;91:467-485.

20. Hill D, Inskip P, Shapiro W, et al. Cancer in first-degree relatives and risk of glioma in adults. Cancer Epidemiol Biomarkers Prev 2003;12:1443-1448.

21. Malmer B, Gronberg H, Bergenheim A, et al. Familial aggregation of astrocytoma in northern Sweden: an epidemiological cohort study. Int J Cancer 1999;81:366-370.

22. Malmer B, Henriksson R, Gronberg H. Familial brain tumoursgenetics or environment? A nationwide cohort study of cancer risk in spouses and first-degree relatives of brain tumour patients. Int J Cancer 2003;106:260-263.

23. Scheurer M, Etzel C, Liu M, et al. Aggregation of cancer in first-degree relatives of patients with glioma. Cancer Epidemiol Biomarkers Prev 2007;16:2491-2495.

24. Tachibana I, Smith J, Sato K, et al. Investigationof germline PTEN, p53, p16(INK4A)/p14(ARF), and CDK4 alterations in familial glioma. Am J Med Genet 2000;92:136-141.

25. Paunu N, Syrjakoski K, Sankila R, et al. Analysis of p53 tumor suppressor gene in families with multiple glioma patients. J Neuro oncol 2001;55:159-165.

26. Paunu N, Lahermo P, Onkamo P, et al. A novel low-penetrance locus for familial glioma at 15q23-q26.3. Cancer Res 2002;62: 3798-3802.

27. Bredel M, Bredel C, Juric D, et al. High-resolution genome-wide mapping of genetic alterations in human glial brain tumors. Cancer Res 2005;65:4088-4096.

28. Wong K, Tsang Y, Chang Y, et al. Genome-wide allelic imbalance analysis of pediatric gliomas by single nucleotide polymorphic allele array. Cancer Res 2006;66:11172-11178.

29. Zhou K, Liu Y, Zhang H, et al. XRCC3 haplotypes and risk of gliomas in a Chinese population: a hospital-based case-control study. Int J Cancer 2009;124:2948-2953.

30. Kiuru A, Lindholm C, Heinavaara S, et al. XRCC1 and XRCC3 variants and risk of glioma and meningioma. J Neuro Oncol 2008;88:135-142.

31. Liu Y, Zhou K, Zhang H, et al. Polymorphisms of LIG4 and XRCC4 involved in the NHEJ pathway interact to modify risk of glioma. Human Mut 2008;29:381-389.

32. Liu Y, Zhang H, Zhou K, et al. Tagging SNPs in non-homologous end-joining pathway genes and risk of glioma. Carcinogenesis 2007;28:1906-1913.

33. Wang L, Bondy M, Shen H, et al. Polymorphisms of DNA repair genes and risk of glioma. Cancer Res 2004;64:5560-5563. 
34. Chang J, Yeh R, Wiencke J, et al. Pathway analysis of singlenucleotide polymorphisms potentially associated with glioblastoma multiforme susceptibility using random forests. Cancer Epidemiol Biomarkers Prev 2008;17:1368-1373.

35. Liu Y, Scheurer M, El-Zein R, et al. Association and interactions between DNA repair gene polymorphisms and adult glioma. Cancer Epidemiol Biomarkers Prev 2009;18:204-214.

36. Chen P, Wiencke J, Aldape K, et al. Association of an ERCC1 polymorphism with adult-onset glioma. Cancer Epidemiol Biomarkers Prev 2000;9:843-847.

37. Wrensch M, Kelsey K, Liu M, et al. ERCC1 and ERCC2 polymorphisms and adult glioma. Neuro-Oncol 2005;7:495-507.

38. Caggana M, Kilgallen J, Conroy J, et al. Associations between ERCC2 polymorphisms and gliomas. Cancer Epidemiol Biomarkers Prev 2001;10:355-360.

39. Yang P, Kollmeyer T, Buckner K, et al. Polymorphisms in GLTSCR1 and ERCC2 are associated with the development of oligodendrogliomas. Cancer 2005;103:2363-2372.

40. Felini M, Olshan A, Schroeder J, et al. DNA repair polymorphisms XRCC1 and MGMT and risk of adult gliomas. Neuroepidemiol 2007;29:55-58.

41. Inoue R, Isono M, Abe M, et al. A genotype of the polymorphic DNA repair gene MGMT is associated with de novo glioblastoma. Neurol Res 2003;25:875-879.

42. Bethke L, Webb E, Murray A, et al. Comprehensive analysis of the role of DNA repair gene polymorphisms on risk of glioma. Human Mol Genet 2008;17:800-805.

43. Pinto G, Yoshioka F, Silva R, et al. Prognostic value of TP53 Pro47Ser and Arg72Pro single nucleotide polymorphisms and the susceptibility to gliomas in individuals from Southeast Brazil. Genet Mol Res 2008;7:207-216.

44. Sadetzki S, Flint-Richter P, Starinsky S, et al. Genotyping of patients with sporadic and radiation-associated meningiomas. Cancer Epidemiol Biomarkers Prev 2005;14:969-976.

45. Leone P, Mendiola M, Alonso J, et al. Implications of a RAD54L polymorphism $(2290 \mathrm{C} / \mathrm{T})$ in human meningiomas as a risk factor and/or a genetic marker. BMC Cancer 2003;3:6.

46. Parhar P, Ezer R, Shao Y, et al. Possible association of p53 codon 72 polymorphism with susceptibility to adult and pediatric highgrade astrocytomas. Brain Res Mol Brain Res 2005;137:98-103.

47. Chen P, Iavarone A, Fick J, et al. Constitutional p53 mutations associated with brain tumors in young adults. Cancer Genet Cytogenet 1995;82:106-115.

48. Zhou X, Sanson M, Hoang-Xuan K, et al. Germline mutations of p53 but not p16/CDKN2 or PTEN/MMAC1 tumor suppressor genes predispose to gliomas. Ann Neurology 1999;46:913-916.

49. Hayashi Y, Yamashita J, Watanabe T. Molecular genetic analysis of deep-seated glioblastomas. Cancer Genet Cytogenet 2004;153: $64-68$.

50. Bhowmick D, Zhuang Z, Wait S, et al. A functional polymorphism in the EGF gene is found with increased frequency in glioblastoma multiforme patients and is associated with more aggressive disease. Cancer Res 2004;64:1220-1223.

51. Carpentier C, Laigle-Donadey F, Marie Y, et al. Polymorphism in $\mathrm{Sp} 1$ recognition site of the EGF receptor gene promoter and risk of glioblastoma. Neurol 2006;67:872-874.

52. Costa B, Ferreira P, Costa S, et al. Association between functional EGF+61 polymorphism and glioma risk. Clin Cancer Res 2007; 13:2621-2626.

53. Vauleon E, Auger N, Benouaich-Amiel A, et al. The 61 A/G EGF polymorphism is functional but is neither a prognostic marker nor a risk factor for glioblastoma. Cancer Genet Cytogenet 2007;172: 33-37.

54. Hayashi Y, Ueki K, Waha A, et al. Association of EGFR gene amplification and CDKN2 (p16/MTS1) gene deletion in glioblastoma multiforme. Brain Pathol 1997;7:871-875.

55. Barbosa K, Oba-Shinjo S, Uno M, et al. Association of EGFR c. $2073 \mathrm{~A}>\mathrm{T}$ polymorphism with decreased risk of diffusely infiltrating astrocytoma in a Brazilian case-control study. Int J Biol Markers 2008;23:140-146.

56. Smith J, Tachibana I, Passe S, et al. PTEN mutation, EGFR amplification, and outcome in patients with anaplastic astrocy- toma and glioblastoma multiforme. J Natl Cancer Inst 2001;93:1246-1256.

57. Kato H, Fujimura M, Kumabe T, et al. PTEN gene mutation and high MIB-1 labeling index may contribute to dissemination in patients with glioblastoma. J Clin Neurosci 2004;11:37-41.

58. Tunca B, Bekar A, Cecener G, et al. Impact of novel PTEN mutations in Turkish patients with glioblastoma multiforme. J Neuro Oncol 2007;82:263-269.

59. Khatri R, Navaratne K, Weil R. The role of a single nucleotide polymorphism of MDM2 in glioblastoma multiforme. J Neurosurg 2008;109:842-848.

60. Tsuiki H, Nishi T, Takeshima H, et al. Single nucleotide polymorphism 309 affects murin-double-minute 2 protein expression but not glioma tumorigenesis. Neurol Med Chir 2007;47:203208.

61. Godfraind C, Rousseau E, Ruchoux M, et al. Tumour necrosis and microvascular proliferation are associated with $9 \mathrm{p}$ deletion and CDKN2A alterations in 1p/19q-deleted oligodendrogliomas. Neuropathol Appl Neurobiol 2003;29:462-471.

62. Gao L, Liu L, van Meyel D, et al. Lack of germ-line mutations of CDK4, p16(INK4A), and p15(INK4B) in families with glioma. Clin Cancer Res 1997;3:977-981.

63. Tada K, Kochi M, Saya H, et al. Preliminary observations on genetic alterations in pilocytic astrocytomas associated with neurofibromatosis 1. Neuro Oncol 2003;5:228-234.

64. Gallia G, Rand V, Siu I, et al. PIK3CA gene mutations in pediatric and adult glioblastoma multiforme. Mol Cancer Res 2006; 4:709-714.

65. McCready J, Broaddus W, Sykes V, et al. Association of a single nucleotide polymorphism in the matrix metalloproteinase-1 promoter with glioblastoma. Int J Cancer 2005;117:781-785.

66. Lu Z, Wang Y, Zhang Q, et al. Association between the functional polymorphism in the matrix metalloproteinase-7 promoter and susceptibility to adult astrocytoma. Brain Res 2006;1118:61112.

67. Chen P, Wiencke J, Conway K, et al. Lack of association of rare alleles in the HRAS variable number of tandem repeats (VNTR) region with adult glioma. Neuro Oncol 2000;2:120-124.

68. Bethke L, Sullivan K, Webb E, et al. The common D302H variant of CASP8 is associated with risk of glioma. Cancer Epidemiol Biomarkers Prev 2008;17:987-989.

69. Rodero M, Marie Y, Coudert M, et al. Polymorphism in the microglial cell-mobilizing CX3CR1 gene is associated with survival in patients with glioblastoma. J Clin Oncol 2008;26:59575964.

70. Rajaraman P, Wang S, Rothman N, et al. Polymorphisms in apoptosis and cell cycle control genes and risk of brain tumors in adults. Cancer Epidemiol Biomarkers Prev 2007;16:1655-1661.

71. De Roos A, Rothman N, Brown M, et al. Variation in genes relevant to aromatic hydrocarbon metabolism and the risk of adult brain tumors. Neuro Oncol 2006;8:145-155.

72. De Roos A, Rothman N, Inskip P, et al. Genetic polymorphisms in GSTM1, -P1, -T1, and CYP2E1 and the risk of adult brain tumors. Cancer Epidemiol Biomarkers Prev 2003;12:14-22.

73. Rajaraman P, Hutchinson A, Rothman N, et al. Oxidative response gene polymorphisms and risk of adult brain tumors. Neuro Oncol 2008;10:709-715.

74. Ezer R, Alonso M, Pereira E, et al. Identification of glutathione $\mathrm{S}$-transferase (GST) polymorphisms in brain tumors and association with susceptibility to pediatric astrocytomas. J Neuro Oncol 2002;59:123-134.

75. Schwartzbaum J, Ahlbom A, Lonn S, et al. An international case-control study of glutathione transferase and functionally related polymorphisms and risk of primary adult brain tumors. Cancer Epidemiol Biomarkers Prev 2007;16:559-565.

76. Trizna Z, de Andrade M, Kyritsis A, et al. Genetic polymorphisms in glutathione S-transferase mu and theta, N-acetyltransferase, and CYP1A1 and risk of gliomas. Cancer Epidemiol Biomarkers Prev 1998;7:553-555.

77. Peters E, Kelsey K, Wiencke J, et al. NAT2 and NQO1 polymorphisms are not associated with adult glioma. Cancer Epidemiol Biomarkers Prev 2001;10:151-152. 
78. Kafadar A, Ergen A, Zeybek U, et al. Paraoxonase 192 gene polymorphism and serum paraoxonase activity in high grade gliomas and meningiomas. Cell Bioche Funct 2006;24:455-460.

79. Searles Nielsen S, Mueller B, De Roos A, et al. Risk of brain tumors in children and susceptibility to organophosphorus insecticides: the potential role of paraoxonase (PON1). Environ Health Perspect 2005;113:909-913.

80. Bethke L, Webb E, Murray A, et al. Functional polymorphisms in folate metabolism genes influence the risk of meningioma and glioma. Cancer Epidemiol Biomarkers Prev 2008;17:1195-1202.

81. Semmler A, Simon M, Moskau S, et al. The methionine synthase polymorphism c. $2756 \mathrm{~A}>\mathrm{G}$ alters susceptibility to glioblastoma multiforme. Cancer Epidemiol Biomarkers Prev 2006;15: 2314-2316.

82. Wrensch M, Kelsey K, Liu M, et al. Glutathione-S-transferase variants and adult glioma. Cancer Epidemiol Biomarkers Prev 2004;13:461-467.

83. Miller K, Kelsey K, Wiencke J, et al. The C3435T polymorphism of MDR1 and susceptibility to adult glioma. Neuroepidemiology 2005;25:85-90.

84. Lai R, Crevier L, Thabane L. Genetic polymorphisms of glutathione S-transferases and the risk of adult brain tumors: a meta-analysis. Cancer Epidemiol Biomarkers Prev 2005;14:1784-1790.

85. Huncharek M, Kupelnick B, Wheeler L. Dietary cured meat and the risk of adult glioma: a meta-analysis of nine observational studies. J Environ Pathol, Toxicol Oncol 2003;22:129-137.

86. Scheurer M, Amirian E, Cao Y, et al. Polymorphisms in the interleukin-4 receptor gene are associated with better survival in patients with glioblastoma. Clin Cancer Res 2008;14:6640-6646.

87. Wiemels J, Wiencke J, Kelsey K, et al. Allergy-related polymorphisms influence glioma status and serum IgE levels. Cancer Epidemiol Biomarkers Prev 2007;16:1229-1235.

88. Schwartzbaum J, Ahlbom A, Malmer B, et al. Polymorphisms associated with asthma are inversely related to glioblastoma multiforme. Cancer Res 2005;65:6459-6465.

89. Schwartzbaum J, Ahlbom A, Lonn S, et al. An international case-control study of interleukin-4Ralpha, interleukin-13, and cyclooxygenase-2 polymorphisms and glioblastoma risk. Cancer Epidemiol Biomarkers Prev 2007;16:2448-2454.

90. Brenner A, Butler M, Wang S, et al. Single-nucleotide polymor- phisms in selected cytokine genes and risk of adult glioma. Carcinogenesis 2007;28:2543-2547.

91. Amirian E, Y Liu, Scheurer M, et al. Interaction among genetic variants in inflammation pathway genes and asthma in glioma susceptibility. Neuro Oncology. In press 2009.

92. Frigerio S, Ciusani E, Pozzi A, et al. Tumor necrosis factor microsatellite polymorphisms in Italian glioblastoma patients. Cancer Genet Cytogenet 1999;109:172-174.

93. Linos E, Raine T, Alonso A, et al. Atopy and risk of brain tumors: a meta-analysis. J Natl Cancer Inst 2007;99:1544-1550.

94. Parsons D, Jones S, Zhang X, et al. An integrated genomic analysis of human glioblastoma multiforme. Science 2008;321: 1807-1812.

95. Yan H, Parsons D, Jin G, et al. IDH1 and IDH2 mutations in gliomas. N Engl J Med 2009;19:360:765-773.

96. Carpentier C, Lejeune J, Gros F, et al. Association of telomerase gene hTERT polymorphism and malignant gliomas. J Neuro Oncol 2007;84:249-253.

97. Onilude O, Lusher M, Lindsey J, et al. APC and CTNNB1 mutations are rare in sporadic ependymomas. Cancer Genet $\mathrm{Cy}-$ togenet 2006;168:158-161.

98. Lonn S, Rothman N, Shapiro W, et al. Genetic variation in insulin-like growth factors and brain tumor risk. Neuro Oncol 2008; 10:553-559.

99. Rajaraman P, Stewart P, Samet J, et al. Lead, genetic susceptibility, and risk of adult brain tumors. Cancer Epidemiol Biomarkers Prev 2006;15:2514-2520.

100. Rajaraman P, Schwartz B, Rothman N, et al. Delta-aminolevulinic acid dehydratase polymorphism and risk of brain tumors in adults. Environ Health Perspect 2005;113:1209-1211.

101. Bardakci F, Arslan S, Bardakci S, et al. Sulfotransferase 1A1 (SULT1A1) polymorphism and susceptibility to primary brain tumors. J Cancer Res Clin Oncol 2008;134:109-114.

102. Malmer B, Adatto P, Armstrong G, et al. GLIOGENE-an international consortium to understand familial glioma. Cancer Epidemiol Biomarkers Prev 2007;16:1730-1733.

103. McLendon R, Friedman A, Bigner D, et al. Comprehensive genomic characterization defines human glioblastoma genes and core pathways. Nature 2008;455:1061-1068. 